\title{
Metamorphic olivine records external fluid infiltration during serpentinite dehydration
}

\author{
E. Clarke ${ }^{1}$, J.C.M. De Hoog ${ }^{1 *}$, L.A. Kirstein ${ }^{1}$, J. Harvey ${ }^{2}$, B. Debret ${ }^{3}$
}

Abstract

doi: 10.7185/geochemlet.2039

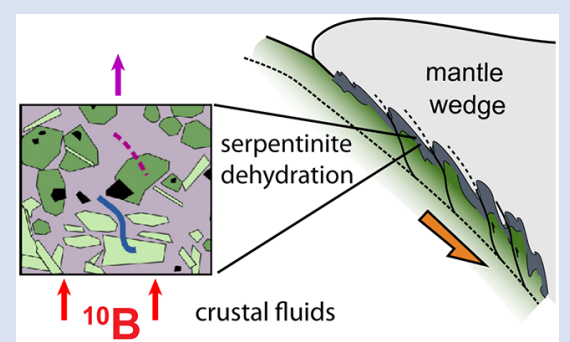

We used boron (B) isotope systematics of co-existing olivine and serpentine to study deep fluid flow in subduction zones. Metamorphic olivine produced by serpentine dehydration at sub-arc conditions from high pressure ophiolites in the Western Alps contains significant concentrations of B $(2-30 \mu \mathrm{g} / \mathrm{g})$ with a high $\delta^{11} \mathrm{~B}$ values $(+9$ to $+28 \%$ ), whilst co-existing serpentine has $2-50 \mu \mathrm{g} / \mathrm{g} \mathrm{B}$ with $\delta^{11} \mathrm{~B}=+6$ to $+24 \%$. Boron isotope fractionation between olivine and its precursor serpentine $\left(\Delta^{11} \mathrm{~B}_{\mathrm{ol}-\mathrm{srp}}=\right.$ $\left.\delta^{11} \mathrm{~B}_{\mathrm{ol}}-\delta^{11} \mathrm{~B}_{\mathrm{srp}}\right)$ is highly variable, which indicates significant isotopic disequilibrium between these minerals. Importantly, samples with B-enriched olivine have low $\Delta^{11} \mathrm{~B}_{\text {ol-srp }}$ (down to $-9 \%$ ), evidence that olivine grew in the presence of a mixture of serpentine-derived fluids and external fluids with $\delta^{11} \mathrm{~B}$ of $c a$. +6 to $+15 \%$ o. The composition of these external fluids is consistent with those from subducting sediments and altered oceanic crust at 50 $80 \mathrm{~km}$ depth, and at least $15-45 \%$ fluid addition. Our work shows that large scale slab fluid infiltration and fluid-mobile element transport accompanies serpentinite dehydration in subduction zones.

Received 12 August 2020 | Accepted 25 October 2020 | Published 23 December 2020

\section{Introduction}

The recycling of lithosphere-hosted volatile and fluid-mobile elements (e.g., $\mathrm{H}_{2} \mathrm{O}, \mathrm{CO}_{2}, \mathrm{~B}$, halogens) back into the convecting mantle via subduction has been crucial for Earth's evolution. Down-dragged mantle wedge serpentinites and hydrated oceanic mantle are water-rich (up to 13 wt. $\% \mathrm{H}_{2} \mathrm{O}$ ), and increasingly recognised as important sources of water and fluid-mobile elements (Deschamps et al., 2013; Scambelluri et al., 2019). However, many details of serpentinite dehydration in subduction zones are still poorly understood, including the relative roles of mantle wedge vs. ocean floor serpentinites (Martin et al., 2020) and B isotope fractionation during serpentine breakdown (De Hoog et al., 2014). Previous work on B behaviour during de-serpentinisation in subduction settings focussed on whole rock geochemistry (Harvey et al., 2014; Cannaò et al., 2015), which obscures the detailed record of fluid-rock interaction preserved in individual mineral phases.

Metamorphic olivine is formed during breakdown of brucite or antigorite (high pressure serpentine) at $\sim 400{ }^{\circ} \mathrm{C}$ and $\sim 650{ }^{\circ} \mathrm{C}$, respectively (Scambelluri et al., 2004) and is B-rich (up to $100 \mu \mathrm{g} / \mathrm{g}$; Scambelluri et al., 2004; De Hoog et al., 2014) compared to primary mantle olivine $(<0.11 \mu \mathrm{g} / \mathrm{g}$; Ottolini et al., 2004). The incorporation of B in metamorphic olivine uniquely records fluid processes during serpentinite dehydration and allows insight into the composition, evolution and origin of these fluids.

Here we present in situ $\delta^{11} \mathrm{~B}$ data of co-existing serpentine and metamorphic olivine from high pressure serpentinites, which show significant disequilibrium between the two minerals. We interpret this as evidence for the infiltration of externally derived fluids during serpentinite dehydration, attesting to complex fluid pathways near the slab-wedge interface.

\section{Samples and their Geological Setting}

To capture the dehydration process, we selected eight serpentinite samples with phase assemblages between the brucite-out and antigorite-out phase transitions with 20-40 \% modal olivine from three ophiolites in the Western Alps (Fig. 1). The Monviso Lago Superiore Unit (LSU) is a shear zone which underwent lawsonite-eclogite facies metamorphism and likely represents a serpentinite channel on the interface between the subducting plate and overlying mantle (Guillot et al., 2004). The Zermatt-Saas ophiolite represents relict oceanic lithosphere of the Mesozoic Tethys ocean subducted to $\sim 60-70 \mathrm{~km}$ : samples were obtained from near Zermatt and from Val d'Aosta. The Erro-Tobbio metaperidotites in the Voltri massif were subducted to 2.0-2.5 GPa and 550-600 ${ }^{\circ} \mathrm{C}$ and represent a subduction channel domain. See Supplementary Information for further sample details.

\section{Boron Isotope Systematics of Olivine and Serpentine}

Boron isotope ratios and concentrations were measured by SIMS at the Edinburgh Ion Microprobe Facility. Matrix-matched

\footnotetext{
School of GeoSciences, Grant Institute, The University of Edinburgh, James Hutton Road, EH9 3FE, United Kingdom

School of Earth and Environment, The University of Leeds, LS2 9JT, United Kingdom

Institut de Physique du Globe de Paris, Sorbonne Paris Cité, Université Paris Diderot, CNRS UMR 7154, Paris, France

Corresponding author (email: ceesjan.dehoog@ed.ac.uk)
} 


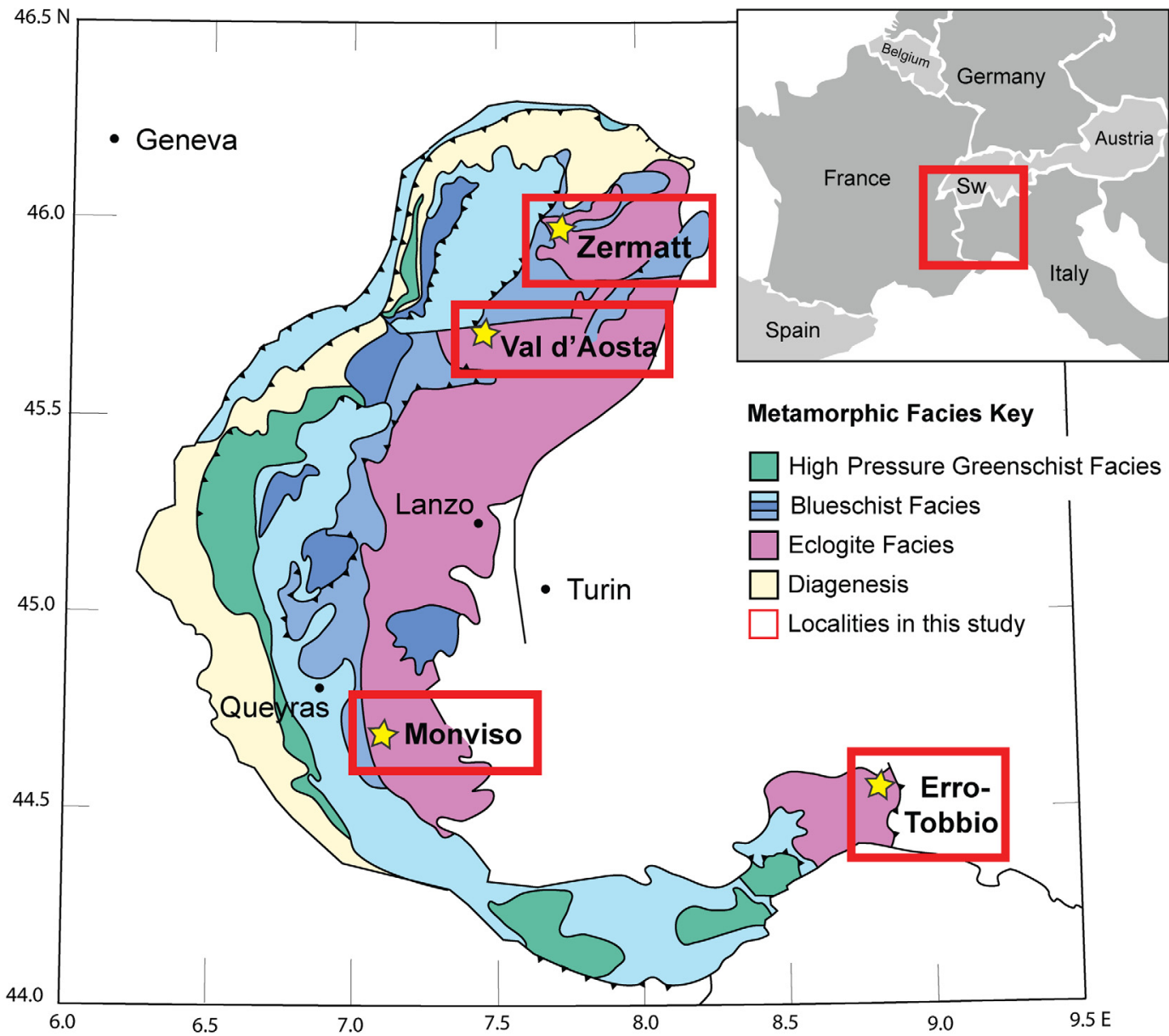

Figure 1 Metamorphic facies map of the Western Alps (after Bousquet et al., 2012) showing study areas and sample locations.

standards including serpentine and olivine with known B isotope compositions were used for calibration. Typical uncertainty for B isotope analyses is $\pm 1.6 \%$ o (1s). Further analytical details and the complete dataset can be found in the Supplementary Information.

Olivine and serpentine show high $\delta^{11} \mathrm{~B}(+6$ to $+28 \%$ ) in all samples (Fig. 2). Minor phases present in some samples include pyroxene, chlorite and clinohumite. Clinohumite has similar [B] as olivine ( 4.8 to $6.5 \mu \mathrm{g} / \mathrm{g}$ ), but very low modal abundance. Pyroxene and chlorite have low $[\mathrm{B}](<2 \mu \mathrm{g} / \mathrm{g})$ compared to olivine and serpentine and can be ignored for the overall $\mathrm{B}$ budget.

On average, Monviso metamorphic olivine shows lower $\delta^{11} \mathrm{~B}$ and higher $[\mathrm{B}]\left(\delta^{11} \mathrm{~B}=+8\right.$ to $+14 \%$, $\left.[\mathrm{B}] \sim 16 \mu \mathrm{g} / \mathrm{g}\right)$ than co-existing serpentine $\left(\delta^{11} \mathrm{~B}=+18\right.$ to $+21 \%$ o, $\left.[\mathrm{B}] \sim 6 \mu \mathrm{g} / \mathrm{g}\right)$. Erro-Tobbio olivine has slightly higher $\delta^{11} \mathrm{~B}$ and $[\mathrm{B}]\left(\delta^{11} \mathrm{~B}+18\right.$ to $+20 \%$, [B] $\sim 11 \mu \mathrm{g} / \mathrm{g})$ than co-existing serpentine $\left(\delta^{11} \mathrm{~B}+16\right.$ to $+17 \%$ o, [B] $\sim 10 \mu \mathrm{g} / \mathrm{g}$ ). Zermatt olivine shows a wide range of $\delta^{11} \mathrm{~B}(+16$ to $+28 \%$ o) and is higher on average than serpentine $\left(\delta^{11} \mathrm{~B}=+6\right.$ to $+21 \%$ ), but lower [B] $(\sim 4 \mu \mathrm{g} / \mathrm{g})$ in olivine compared to serpentine $(\sim 8 \mu \mathrm{g} / \mathrm{g})$. The Val d'Aosta sample has higher $[\mathrm{B}]$ in olivine vs. serpentine $(22 v s .10 \mu \mathrm{g} / \mathrm{g})$ but somewhat lower $\delta^{11} \mathrm{~B}(+17$ to $+19 \%$ in olivine, +16 to $+21 \%$ o in serpentine).

The most striking aspect of our dataset is the large variation in $\mathrm{B}$ isotope fractionation between olivine and serpentine $\left(\Delta^{11} \mathrm{~B}_{\mathrm{ol}-\text { srp }} ; \delta^{11} \mathrm{~B}_{\mathrm{ol}}-\delta^{11} \mathrm{~B}_{\text {srp }}\right.$ of co-existing olivine and serpentine) which shows that olivine is often not in isotopic equilibrium with serpentine, despite being its daughter product. Our dataset also shows a clear covariation between $\Delta^{11} \mathrm{~B}_{\mathrm{ol}-\text { srp }}$ and B-enrichment in olivine $\left([\mathrm{B}]_{\mathrm{ol} / \mathrm{srp}}:[\mathrm{B}]_{\mathrm{ol}} /[\mathrm{B}]_{\mathrm{srp}}\right)$ : Zermatt metamorphic olivine is depleted in $\mathrm{B}$ compared to co-existing serpentine but has heavier $\delta^{11} \mathrm{~B}$ (Fig. 3). Monviso and Val d'Aosta olivine, however, is enriched in $\mathrm{B}$ compared to the co-existing serpentine but has lower $\delta^{11} \mathrm{~B}$. Erro-Tobbio olivine lies between these two extremes with roughly similar $[\mathrm{B}]$ and $\delta^{11} \mathrm{~B}$ in olivine and serpentine. As the measured olivine is metamorphic and grew upon serpentinite dehydration, protolith composition and heterogeneity have no bearing on $[\mathrm{B}]_{\mathrm{ol} / \text { srp }}$ and $\Delta^{11} \mathrm{~B}_{\mathrm{ol} \text {-srp, }}$ therefore processes operating during olivine growth are needed to explain these observations.

\section{Fluid Infiltration during Serpentine Dehydration}

No partitioning data for $\mathrm{B}$ between serpentine and olivine $\left(\mathrm{D}_{\mathrm{B}}{ }^{\mathrm{ol}}\right.$ srp) is available, but a value of $3-5$ for $D_{B}{ }^{\text {fluid/residue }}$ was recorded during serpentinite dehydration experiments with olivine as the main reservoir for B in the residue (Tenthorey and Hermann, 2004). Given this, mass balance dictates that $\mathrm{D}_{\mathrm{B}}{ }^{\text {ol/srp }} \sim 0.6-0.9$ (see Supplementary Information), and higher values indicate excess B in olivine. Samples from Zermatt show $[\mathrm{B}]_{\mathrm{ol} / \text { srp }}$ 0.40.9 , close to the expected equilibrium value. This is accompanied by $\Delta^{11} \mathrm{~B}_{\mathrm{ol}-\mathrm{srp}}$ of +7.4 to $+14.6 \%$ (Fig. 3 ). In most silicates, including serpentine, $\mathrm{B}^{3+}$ substitutes for $\mathrm{Si}^{4+}$ or $\mathrm{Al}^{3+}$ in tetrahedral (IV) coordination (Hervig et al., 2002; Pabst et al., 2011). In mantle 


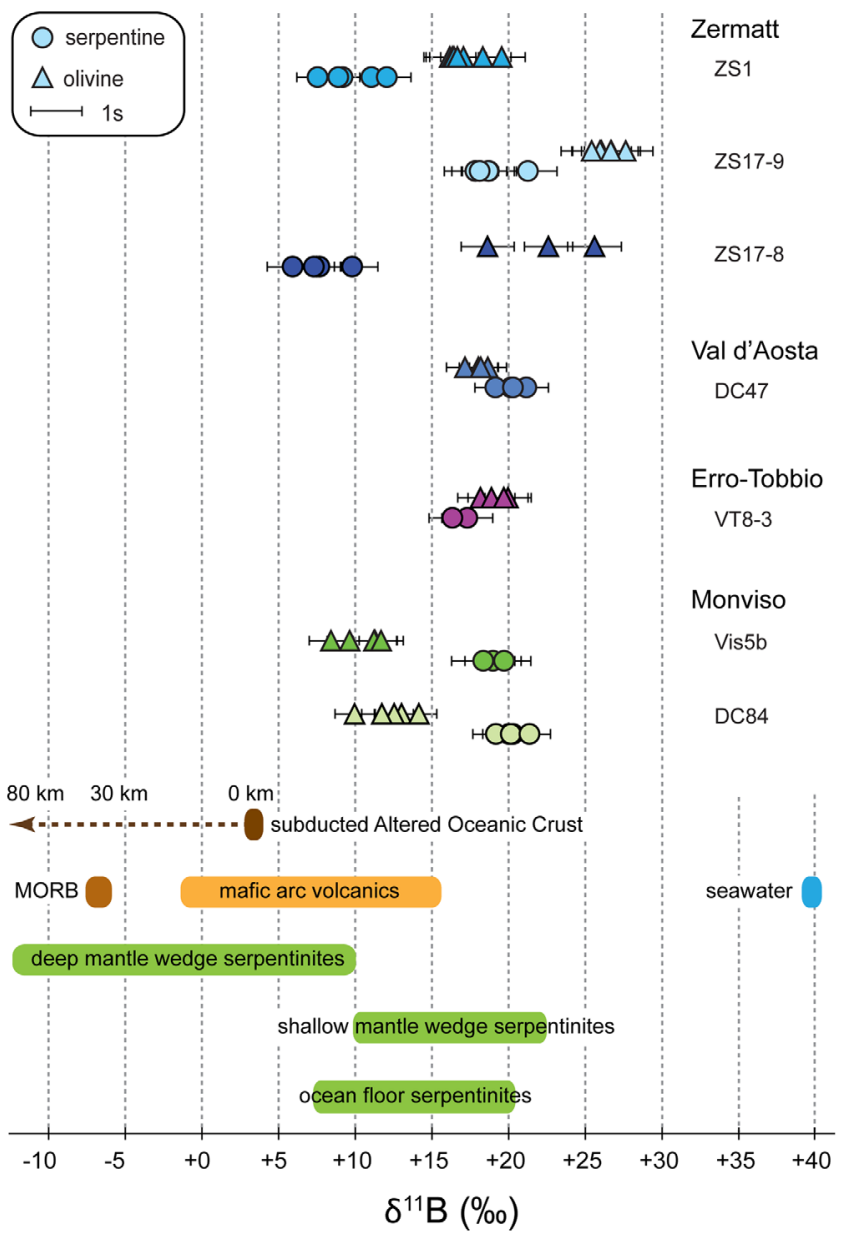

Figure $2 \delta^{11} \mathrm{~B}$ data for olivine and serpentine in our samples. Error bars represent 1s uncertainties and include calibration uncertainties. Also indicated are B isotope compositions of various reservoirs relevant to subduction zones (data sources: Tonarini et al., 2011; De Hoog and Savov, 2018 and references therein; Martin et al., 2020).

silicates such as clinopyroxene and olivine, B also substitutes for $\mathrm{Si}^{4+}$ but occurs in trigonal (III) coordination as a $\mathrm{BO}_{3}$ group (Hålenius et al., 2010; Ingrin et al., 2014). As ${ }^{11} \mathrm{~B}$ preferentially resides in trigonal and ${ }^{10} \mathrm{~B}$ in tetrahedral coordination (Kowalski et al., 2013), olivine with trigonal B will show a heavier B isotope signature than co-existing serpentine with tetrahedral B. For the Zermatt samples, $\Delta^{11} \mathrm{~B}_{\mathrm{ol}-\text { srp }}$ is close to the experimentally determined equilibrium $B$ isotope fractionation between III and IV phases, which decreases from $\Delta^{11} \mathrm{~B}_{\mathrm{ol}-\mathrm{srp}}=+12.5$ to $+8.5 \%$ o with $\mathrm{T}$ increasing from 450 to $650{ }^{\circ} \mathrm{C}$ (Kowalski et al., 2013).

Therefore, we conclude that Zermatt metamorphic olivine was in equilibrium with internal fluids released during dehydration of serpentine, with no evidence for contamination by external fluids. This conclusion is supported by REE and Sr isotope data (Gilio et al., 2019) and consistent with the geological setting of the Zermatt samples, which come from a thick $(\sim 2 \mathrm{~km})$ coherent section of subducted ocean lithosphere. The range in $\Delta^{11} \mathrm{~B}_{\mathrm{ol}-\mathrm{srp}}$ of +7.4 to $+14.6 \%$ is probably related to metamorphic olivine forming at different temperatures during antigorite-out and brucite-out reactions, respectively.

The majority of metamorphic olivines from localities other than Zermatt have $[\mathrm{B}]_{\mathrm{ol} / \text { srp }}>1$ and $\Delta^{11} \mathrm{~B}_{\mathrm{ol} \text {-srp }}<+5 \%$, i.e. more $\mathrm{B}$ and ${ }^{10} \mathrm{~B}$ in olivine than is expected for growth during equilibrium dehydration of serpentine (Fig. 3). The most likely source of



Figure 3 Diagram comparing boron isotope systematics of cOexisting metamorphic olivine and serpentine. $[\mathrm{B}]_{\mathrm{ol} / \mathrm{srp}}=[\mathrm{B}]_{\text {olivine }} /$ $[\mathrm{B}]_{\text {serpentine, }}$ and $\Delta^{11} \mathrm{~B}_{\mathrm{ol}-\text { srp }}=\delta^{11} \mathrm{~B}$ of olivine $-\delta^{11} \mathrm{~B}$ of serpentine. Large symbols with $1 \mathrm{~s}$ error bars indicate averages for each sample, whereas small symbols represent all possible olivine-serpentine pairs for each sample (see Supplementary Information for details). A broadly negative correlation between $[\mathrm{B}]_{\mathrm{o} / \text { srp }}$ and $\Delta^{11} \mathrm{~B}_{\text {ol-srp }}$ is observed. Grey bars indicate equilibrium fractionation of boron and its isotopes at relevant $P$ - $T$ conditions.

excess B is external fluid, as no other B-rich phases that dehydrate at $450-650{ }^{\circ} \mathrm{C}$ were present. Scarce clinohumite is B-rich but stable at the prevailing $P-T$ conditions (Shen et al., 2015) and its breakdown products (ilmenite, rutile) were not observed. Thus, we envisage a model where fluid from serpentine dehydration mixed with infiltrating external fluid, and metamorphic olivine grew in equilibrium with this mixed fluid. Serpentine did not re-equilibrate with this fluid due to sluggish kinetics at these low temperatures $\left(450-650{ }^{\circ} \mathrm{C}\right)$ (e.g., Lafay et al., 2019). Mass balance calculations indicate that these external fluids had $\delta^{11} \mathrm{~B}$ of $+6 \%$ o (Monviso) to $+15 \%$ o (Erro-Tobbio) depending on the B concentration of the external fluids (Fig. S-6) and assuming mildly alkaline $\mathrm{pH}$ conditions for both internal and external fluids (Galvez et al., 2016; Debret and Sverjensky, 2017). This matches the composition of fluids derived from a mixture of altered oceanic crust and sediments from 50-80 km depth (Tonarini et al., 2011; Yamada et al., 2019), consistent with the depth of the serpentinites in the former subduction zone. The external fluids comprise at least $c a .15-45 \%$ of the total fluid budget of the dehydrating serpentinites, which are minimum estimates, as any partial re-equilibration of serpentine would lead to underestimating the amount of external fluid.

\section{Metasomatism near the Subduction Interface}

External fluids may permeate dehydrating serpentinites without the need for large scale faulting, as seen in Erro-Tobbio, which only shows metre scale vein networks and deformation. During serpentine dehydration there is a rapid increase in porosity and rock permeability allowing fluid to drain from the rock without the need for brittle failures and opening of fault pathways (Tenthorey and Cox, 2003; Plümper et al., 2017). The creation of such porosity also provides pathways for significant volumes of B-rich external fluids to infiltrate. 


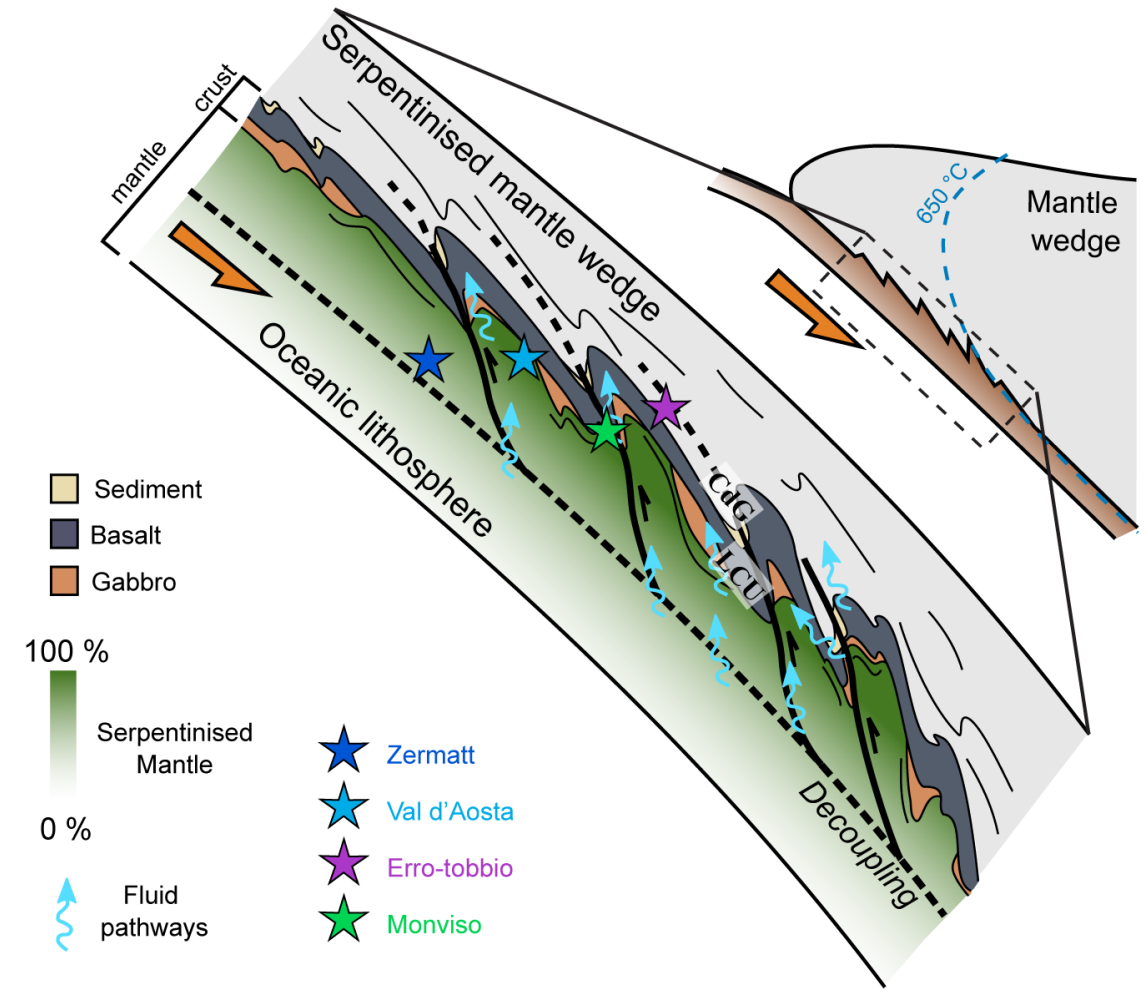

Figure 4 Schematic diagram depicting proposed fluid pathways and setting within the plate interface for serpentinite localities in this study after Gilio et al. (2019), where LCU and CdG indicate positions of Lago di Cignana and Cima di Gagnone HP ophiolites from that publication.

The trend towards higher $[\mathrm{B}]_{\mathrm{ol} / \mathrm{srp}}$ with lower $\Delta^{11} \mathrm{~B}_{\mathrm{ol}-\mathrm{srp}}$ indicates an increasing influence of B-rich external fluids from Zermatt to Erro-Tobbio to Valle d'Aosta to Monviso. This trend correlates with the position of the serpentinite bodies relative to the slabmantle interface during peak metamorphic conditions (Fig. 4). The Monviso ophiolite and Erro-Tobbio massif are thought to represent serpentinite domains between the subducting slab and the mantle wedge (Guillot et al., 2004; Scambelluri and Tonarini, 2012); a prime location to be infiltrated by fluids derived from the subducted slab. Shear zone associated faulting provides many additional pathways for fluid flow throughout the Monviso ophiolite, leaving the serpentinites exposed to extensive interaction with external fluids (Angiboust et al., 2014; Gilio et al., 2020). The Val d'Aosta sample is considered part of the Zermatt-Saas ophiolite but at Val d'Aosta the serpentinite is thinner $(\sim 0.5 \mathrm{~km})$ and surrounded by crustal lithologies (metasediments and metabasalts). This sample shows elevated $[\mathrm{B}]_{\mathrm{ol} / \mathrm{srp}}$ and lower $\Delta^{11} \mathrm{~B}_{\mathrm{ol}-\text { srp }}$ compared to the other Zermatt samples, likely related to its proximity to other lithologies and increased exposure to dehydration fluids.

The micro-scale process where metamorphic olivine grows from a mixture of internal and external fluids would not be detected using whole rock $\delta^{11} \mathrm{~B}$ data, as serpentinites in this study have positive whole rock $\delta^{11} \mathrm{~B}$ (e.g., Scambelluri and Tonarini, 2012) whilst being variably affected by external fluid infiltration. In contrast, subduction mélange serpentinites and metaperidotites with negative $\delta^{11} \mathrm{~B}$ suffered more extensive contamination and extreme $\delta^{11} \mathrm{~B}$ overprinting consistent with their close association with large proportions of crustal rocks and sediments (Cannaò et al., 2015; Martin et al., 2020).

\section{Conclusions}

Metamorphic olivine is a sensitive recorder of the fluid composition from which it grew, and recorded extensive external fluid infiltration during subduction dehydration of Alpine serpentinites, which are sinks and carriers of crust-derived fluid mobile elements. External fluid infiltration was most prominent in serpentinites close to the subduction interface and amounted to up to $45 \%$ of the total dehydration fluid budget. The study of B isotope systematics of texturally co-existing olivine and serpentine provides a powerful tool to study fluid flow deep in subduction zones, and reveals processes not visible in whole rock $\delta^{11} \mathrm{~B}$ compositions.

\section{Acknowledgements}

The authors would like to thank Lukas Baumgartner for his generous help during field work, Marco Scambelluri and Tatsuki Tsujimori for constructive reviews, Horst Marschall for editorial handling, Samuele Agostini, Ray Burgess and Katy Evans for helpful comments on earlier versions of this manuscript, and the NERC 'Deep Volatiles' consortium (NE/M000427/1), NERC-IMF (IMF571/1015; IMF595/0516) and E3-DTP for funding.

Editor: Horst R. Marschall

\section{Additional Information}

Supplementary Information accompanies this letter at https:// www.geochemicalperspectivesletters.org/article2039.

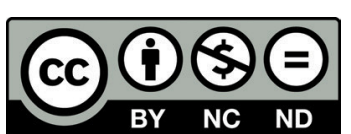

(C) 2020 The Authors. This work is distributed under the Creative Commons Attribution NonCommercial No-Derivatives 4.0 License, which permits unrestricted distribution provided the original author and source are credited. The material may not be adapted (remixed, transformed or built upon) or used for commercial purposes without written permission from the 
author. Additional information is available at https://www. geochemicalperspectivesletters.org/copyright-and-permissions.

Cite this letter as: Clarke, E., De Hoog, J.C.M, Kirstein, L.A. Harvey, J., Debret, B. (2020) Metamorphic olivine records external fluid infiltration during serpentinite dehydration. Geochem. Persp. Let. 16, 25-29.

\section{References}

Angiboust, S., Pettke, T., De Hoog, J.C.M., Caron, B., Oncken, O. (2014) Channelized fluid flow and eclogite-facies metasomatism along the subduction shear zone. Journal of Petrology 55, 883-916.

Bousquet, R., Oberhänsli, R., Schmid, S.M., Berger, A., WiedenkeHR, C.R Möller, A., Rosenberg, C., Zeilinger, G., Molli, G., Koller, F. (2012) Metamorphic framework of the Alps. CCGM-CGMW, Paris.

Cannaò, E., Agostini, S., Scambelluri, M., Tonarini, S., Godard, M. (2015) B, Sr and $\mathrm{Pb}$ isotope geochemistry of high-pressure Alpine metaperidotites monitor fluid-mediated element recycling during serpentinite dehydration in subduction mélange (Cima di Gagnone, Swiss Central Alps). Geochimica et Cosmochimica Acta 163, 80-100.

De Hoog, J.C.M., SAvov, I.P. (2018) Boron Isotopes as a Tracer of Subduction Zone Processes. In: Marschall, H., Foster, G. (Eds.) Boron Isotopes: The Fifth Element. Advances in Isotope Geochemistry. Springer International Publishing, Cham, 217-247.

De Hoog, J.C.M., Hattori, K., Jung, H. (2014) Titanium- and water-rich metamorphic olivine in high-pressure serpentinites from the Voltri Massif (Ligurian Alps, Italy): evidence for deep subduction of high-field strength and fluid-mobile elements. Contributions to Mineralogy and Petrology 167.

DeBret, B., SverjensKY, D.A. (2017) Highly oxidising fluids generated during serpentinite breakdown in subduction zones. Scientific Reports 7, 10351.

Deschamps, F., Godard, M., Guillot, S., Hattori, K. (2013) Geochemistry of subduction zone serpentinites: A review. Lithos 178, 96-127.

Galvez, M.E., Connolly, J.A.D., Manning, C.E. (2016) Implications for metal and volatile cycles from the $\mathrm{pH}$ of subduction zone fluids. Nature $539,420-424$

Gilio, M., Scambelluri, M., Agostini, S., Godard, M., Peters, D., Pettke, T. (2019) Petrology and geochemistry of serpentinites associated with the ultra-high pressure Lago di Cignana Unit (Italian Western Alps). Journal of Petrology 60, 1229-1262.

Gilio, M., Scambelluri, M., Agostini, S., Godard, M., Pettke, T., Agard, P. Locatelli, M., Angiboust, S. (2020) Fingerprinting and relocating tectonic slices along the plate interface: Evidence from the Lago Superiore unit at Monviso (Western Alps). Lithos 352, 105308

Guillot, S., Schwartz, S., Hattori, K., Auzende, A.L., Lardeaux, J. (2004) The Monviso ophiolitic massif (Western Alps), a section through a serpentinite subduction channel. Journal of the Virtual Explorer 16, 1-17.

Hålenius, U., Skogby, H., Eden, M., Nazzareni, S., Kristiansson, P., Resmark, J. (2010) Coordination of boron in nominally boron-free rock forming silicates: Evidence for incorporation of $\mathrm{BO}_{3}$ groups in clinopyroxene. Geochimica et Cosmochimica Acta 74, 5672-5679.

Harvey, J., Garrido, C.J., Savov, I., Agostini, S., Padrón-Navarta, J.A., Marchesi, C, SÁnchez-Vizcaíno, V.L., GómEZ-Pugnaire, M.T. (2014) ${ }^{11}$ B-rich fluids in subduction zones: The role of antigorite dehydration in subducting slabs and boron isotope heterogeneity in the mantle. Chemical Geology 376, 20-30.

Hervig, R.L., Moore, G.M. Williams, L.B., Peacock, S.M. Holloway, J.R Roggensack, K. (2002) Isotopic and elemental partitioning of boron between hydrous fluid and silicate melt. American Mineralogist 87, 769-774.

Ingrin, J., Kovacs, I., Deloule, E., Balan, E., Blanchard, M., Kohn, S.C., Hermann, J (2014) Identification of hydrogen defects linked to boron substitution in synthetic forsterite and natural oliyine. American Mineralogist 99 2138-2141.

KOWALSKI, P.M., WundER, B., JAHN, S. (2013) Ab initio prediction of equilibrium boron isotope fractionation between minerals and aqueous fluids at high $\mathrm{P}$ and T. Geochimica et Cosmochimica Acta 101, 285-301.

Lafay, R., Baumgartner, L.P., Putlitz, B., Siron, G. (2019) Oxygen isotope disequilibrium during serpentinite dehydration. Terra Nova 31, 94-101.

Martin, C., Flores, K.E., Vitale-Brovarone, A., Angiboust, S., Harlow, G.E. (2020) Deep mantle serpentinization in subduction zones: Insight from in situ $B$ isotopes in slab and mantle wedge serpentinites. Chemical Geology 545, 119637.
OtTolini, L., Le FÈvre, B., VAnNucCI, R. (2004) Direct assessment of mantle boron and lithium contents and distribution by SIMS analyses of peridotite minerals. Earth and Planetary Science Letters 228, 19-36.

Pabst, S., Zack, T., SAVov, I.P., Ludwig, T., Rost, D., VicenZI, E.P. (2011) Evidence for boron incorporation into the serpentine crystal structure. American Mineralogist 96, 1112-1119.

Plümper, O., John, T., Podladchikov, Y.Y., VRIJMOed, J.C., ScambelluRi, M. (2017) Fluid escape from subduction zones controlled by channel-forming reactive porosity. Nature Geoscience 10, 150-156

SCAmbelluri, M., TonarinI, S. (2012) Boron isotope evidence for shallow fluid transfer across subduction zones by serpentinized mantle. Geology 40, 907-910.

Scambelluri, M., Müntener, O., Ottolini, L., Pettke, T.T., Vannucci, R. (2004) The fate of $\mathrm{B}, \mathrm{Cl}$ and $\mathrm{Li}$ in the subducted oceanic mantle and in the antigorite breakdown fluids. Earth and Planetary Science Letters 222, 217-234.

Scambelluri, M., Cannaò, E., Gilio, M. (2019) The water and fluid-mobile element cycles during serpentinite subduction. A review. European Journal of Mineralogy 31, 405-428.

Shen, T.T., Hermann, J., Zhang, L.F., Lu, Z., Padrón-Navarta, J.A., XiA, B., Bader, T. (2015) UHP metamorphism documented in Ti-chondrodite- and Ti-clinohumite-bearing serpentinized ultramafic rocks from Chinese Southwestern Tianshan. Journal of Petrology 56, 1425-1457.

TENTHOREY, E., Cox, S.F. (2003) Reaction-enhanced permeability during serpentinite dehydration. Geology 31, 921-924.

Tenthorey, E., Hermann, J. (2004) Composition of fluids during serpentinite breakdown in subduction zones: Evidence for limited boron mobility. Geology 32, $865-868$.

Tonarini, S., LeEMAN, W.P., Leat, P.T. (2011) Subduction erosion of forearc mantle wedge implicated in the genesis of the South Sandwich Island (SSI) arc: Evidence from boron isotope systematics. Earth and Planetary Science Letters 301, 275-284.

YAmada, C., Tsuimori, T., Chang, Q., KimURA, J.I. (2019) Boron isotope variations of Franciscan serpentinites, northern California. Lithos 334, 180-189. 